By: R. Rindu Garveraa; Regi Refian Garisb; Irfan Nursetiawanc; Kiki Endahd The Role of "Jaga Lembur" in Optimization Tourism Services Based on Local Wisdom

\title{
THE ROLE OF “ JAGA LEMBUR” IN OPTIMIZATION TOURISM SERVICES BASED ON LOCAL WISDOM
}

\author{
R. Rindu Garvera, Regi Refian Garis, Irfan Nursetiawan, Kiki Endah \\ Universitas Galuh, Ciamis, Indonesia. \\ email: rindugarvera79@gmail.com
}

\begin{abstract}
The tourism industry has developed into a lead sector in improving people's welfare at the grass root level. But new problems arise over tourism activities, including the existence of social problems such as the number of homeless, buskers, beggars, even crazy people who roam around Pangandaran Beach and of course disturbing order, and security of tourist areas. The Regional Government also made various efforts in disciplining it, one of which was realized by the establishment of a Task Force "Jaga Lembur". Although there are similarities with the role of Pecalang in Bali, the role of Overtime Guard still has its own characteristics. The purpose of this study is to analyze the role of the Task Force on Keep Overtime which focuses on orderliness and security of attractions. This research method is a qualitative descriptive study. The results of this study indicate that the role carried out by Overtime Guard in optimizing services in the tourism sector with local wisdom-based in Pangandaran Regency has been done optimally. Evidenced by the orderly tourism area with no wild homelessness, increased tourist visits and the satisfaction of tourists with Overtime Guard performance by assuming Overtime as a medium for tourism information in Pangandaran Regency, the clothes used by Overtime are environmentally friendly based on local wisdom. This research contributes to local governments as policyholders to innovate in providing public services in the tourism sector by collaborating with the principles of local wisdom.
\end{abstract}

Keywords: Overtime, Service, Tourism, Pangandaran. 
By: R. Rindu Garveraa; Regi Refian Garisb; Irfan Nursetiawanc; Kiki Endahd The Role of "Jaga Lembur" in Optimization Tourism Services Based on Local Wisdom

\section{INTRODUCTION}

In its development, Pangandaran Beach became the main tourist area of Pangandaran Regency, even West Java, which was able to be used as a source of Regional Revenue. The distance of this area from the capital of Pangandaran Regency is $92 \mathrm{Km}$. Geographically located in the coordinates of $108^{\circ} 30-109^{\circ} \mathrm{BT}$ and $7^{\circ} 30-8^{\circ} \mathrm{LS}$ located in the south of West Java, directly facing the Indian Ocean.

Likewise with Pangandaran Regency, a leading destination that has a lot of tourism potential that can be developed. Pangandaran Regency with its tourism icon, Pangandaran Beach has become a National Strategic Area, National Tourism Strategic Area and a priority area for National tourism development. One of the tourism development goals in Pangandaran Regency is to create tourism in Pangandaran Regency as a superior destination at the national and international levels by developing the attraction of natural and cultural tourism and artificial/special interests in an integrated and sustainable way as Indonesia's leading tourism, developing potential and characteristic tourist-based attractions Regions and local communities, Improve supervision and control of the management and maintenance of tourism assets and potential in Pangandaran Regency, realize the tourism industry that is able to drive the regional economy through increased investment in tourism, cooperation between tourism businesses, expanding employment, and carrying out efforts efforts to support environmental preservation and community empowerment; develop tourism institutions and governance systems that are able to synergize the development of the tourism industry, tourism area, and tourism marketing in a professional, effective and efficient manner. Increasing the role and capability of the community in tourism development in Pangandaran Regency, especially by increasing the quality of tourism human resources in the face of higher competition in the world of national and international tourism. Optimizing the benefits received by the Pangandaran Regency community from its regional tourism development by opening the widest opportunity for the community to be involved directly or indirectly at each stage of tourism development.

But apart from all the above objectives, Pangandaran Beach has several social problems that must be resolved, including the number of homeless people, street singers, beggars, even crazy people who roam around Pangandaran Beach and many people who want to contribute by selling, selling services surfing rentals as well as the provision of other services, this may cause chaos around the Pangandaran coast which ultimately disrupts the beauty, order, and comfort of visitors both domestic tourists and foreign tourists. It is clearly the responsibility of the regional government to organize it even better. Based on the General Provisions of Article 1 in Regulations of Regent Pangandaran Number 63 of 2016 concerning Main Tasks, Functions, Job Descriptions and Work Procedures of the Civil Service Police Unit including: a) Civil Service Police Unit is a Regional Government apparatus for maintaining and carrying out peace and public order and enforcing Regional Regulations and other legal products. b) Civil Service Police is a Regional Government apparatus that carries out the duties of the Regional Head in maintaining and carrying out peace and public order, enforcing Regional Regulations and other legal products. c) Peace and public order is a dynamic 
situation that enables the Government, Regional Government and the community to carry out their activities in a peaceful, orderly and orderly manner.

In connection with the provisions above the civil service police unit is responsible for the establishment of a security unit in the tourist attraction area. that in order to increase the participation of the community in maintaining security and order, in particular, to provide comfort for visitors in tourist attractions, an Overtime Guard Task Force has been formed and confirmed by Regent Decree Pangandaran Number 304 / Kpts.387-Huk/ 2018. Based on the background above, the author feels interested in researching further to conduct research on the Role of Overtime Guard in Optimizing Local Wisdom-Based Tourism Services in Pangandaran beach attractions.

\section{METHODOLOGY}

The research method used is a descriptive method, which is describing or describing phenomena that are either natural or engineering. This is in line with the opinion of Nana S. Sukmadinata (2010:330), that descriptive research is a form of research that is the most basic and aimed at describing existing phenomena. The data collection techniques by means of library research, field studies through observation and interviews.

\section{LITERATURE REVIEW}

\subsection{Service Quality}

In Dwimawanti, Ida Hayu (2004) The application of a quality-focused customer system can be successful if we understand the obstacles faced earlier. One of the obstacles that have been found so far is the indifference and powerlessness of the apparatus in implementing a customer-focused quality system. The results of studies of various quality management books conducted by Masters (1996) which were then cited by Gaspersz (1997:265) state that the barriers to developing a quality management system are as follows:

a) Absence of commitment from the management;

b) Absence of knowledge or lack of understanding of quality management;

c) Inability to change culture;

d) The inaccuracy of reward and reward system for employees;

e) Inaccuracy in adopting quality management principles into the organization;

f) Ineffectiveness of measurement techniques and lack of access to data and results;

g) Short-term focus and want the right results;

h) Inaccuracy in giving attention to internal and external customers;

i) Mismatch of conditions for the implementation of quality management;

j) Inaccuracy in using empowerment and cooperation.

Furthermore, Gaspersz (1997: 265) states that the success of developing the quality management of an organization depends on two main things, namely: 1 . The great desire of top management to apply the principles of quality in the organization, and 2. The principle of quality is accommodated in the quality management system. 


\subsection{Tourism}

Tourism can be used as a form of travel carried out by someone in order to meet their secondary needs, in the form of activities for recreation or refreshment after feeling tired in carrying out the routine of daily life (Sunaryo, 2013:3). Therefore, people who travel are referred to as tourists.

\subsection{Local Wisdom}

According to Rahyono in Ulfah Fajarini (2014), local wisdom is human intelligence possessed by certain ethnic groups obtained through community experience, meaning that local wisdom is the result of certain communities through their experience and not necessarily experienced by other communities. These values will be very strongly attached to certain communities and that value has gone through a long time journey, throughout the existence of the community.

\section{RESULTS}

The results of this study indicate that the role carried out by Overtime Guard in optimizing services in the tourism sector with local wisdom-based in Pangandaran Regency has been done optimally. Evidenced by the orderly area of tourism with the absence of wild bums, street vendors who peddle their wares in improper places for example on the beach, on sidewalks for pedestrians and parking areas.

This shows that the phenomenon is causing chaotic conditions and clearly requires handling and anticipation from the local government. This has been implemented through the issuance of the Regent's Decree concerning the establishment and confirmation of Overtime Guard Task Force by Decree of Regent Pangandaran Number 304 / Kpts.387Huk / 2018.

The results of the issuance of the policy can be seen from several indicators including 1) increasing tourist visits and the satisfaction of tourists with Overtime Guard performance, 2) visitors feel facilitated by Overtime Guard as a media for tourism information in Pangandaran Regency, 3) the distinctiveness of clothing used Overtime environmentally friendly is the main attraction and the characteristic that is based on local wisdom by using "pages" as Sundanese traditional clothing, 4) tourists and people around the attraction feel gated because Keep Overtime has the task of curbing and securing in the tourist area for 24 hours. This research contributes to local governments as policyholders to innovate in providing public services in the tourism sector by collaborating with the principles of local wisdom.

\section{CONCLUSION}

From the results of the study, it can be concluded that the policies issued by Pangandaran Regency regarding the establishment of Overtime Guard Task Force have been effectively implemented and this has become a new innovation for the development of new autonomous regions such as Pangandaran Regency by combining modernization and local wisdom. 
Proceeding ICOGISS 2019

Page 157-161. ISBN: 978-602-6 988-75-1

Web Jurnal Online: jurnal.unmuhjember.ac.id

By: R. Rindu Garveraa; Regi Refian Garisb; Irfan Nursetiawanc; Kiki Endahd

The Role of "Jaga Lembur" in Optimization Tourism Services Based on Local Wisdom

\section{REFERENCE}

Nana S. Sukmadinata. 2010. Educational Research Methods. Bandung: Teenager Rosdakarya.

Dwimawanti , Ida Hayu. 2004. Kualitas Pelayanan Publik (Salah Satu Parameter Keberhasilan Otonomi Daerah). Dialogue JIAKP, Vol.1, No.1, hal 109-116.

Bambang Sunaryo. 2013. Kebijakan Pembangunan Destinasi Pariwisata Konsep dan Aplikasinya di Indonesia. Yogyakarta: Gava Media.

Surat Keputusan Bupati Kabupaten Pangandaran tentang Pembentukan dan Pengukuhan Satuan Tugas Jaga Lembur dengan Nomor 304/Kpts.387-Huk/2018.

Ulfah Fajarini. 2014. Peranan Kearifan Lokal Dalam Pendidikan Karakter. Sosio didaktika: Vol. 1. No. 2. 